\title{
Inhibition by Trifluoperazine of Glycogenolytic Effects of Phenylephrine, Vasopressin, and Angiotensin II
}

\author{
YoSHINOBU KOIDE ${ }^{\mathrm{a}}$, SATOSHI KIMURA ${ }^{\mathrm{b}}$, RYOKO TADA ${ }^{\mathrm{a}}$, \\ NoBUo KUGAI ${ }^{\mathrm{a}}$ AND KAMEJIRO YAMASHITA ${ }^{\mathrm{a}}$ \\ ${ }^{a}$ Institute of Clinical Medicine, University of Tsukuba, \\ Sakura-mura, Niihari-gun, Ibaraki 305, and \\ Endocrinology Division, National Cancer Center Research \\ Institute, Tsukiji, Chuo-ku, Tokyo 104
}

\begin{abstract}
The effects of trifluoperazine on the activation of glycogenolysis by various hormones were studied in perfused rat liver. Trifluoperazine significantly inhibited glycogenolytic effect of phenylephrine and angiotensin II by lowering maximal response, and that of vesopressin by shifting the dose-response curve to the right, while $\alpha$-antagonist phentolamine was inhibitory only to phenylephrine. Phosphorylase activation of phenylephrine was inhibited by trifluoperazine in parallel with glycogenolytic response. The increase in ${ }^{45} \mathrm{Ca}^{2+}$ efflux induced by phenylephrine, angiotensin II, and vasopressin was also inhibited by the agent. These inhibitory effects of trifluoperazine were not related to the change in tissue cyclic AMP or cyclic GMP levels. On the other hand, neither the glycogenolytic effect of glucagon, cyclic AMP, and $\mathrm{N}^{6}, \mathrm{O}^{2}$-dibutyryl cylic AMP nor phosphorylase activation by glucagon was affected by trifluoperazine. Thus, trifluoperazine specificially inhibits the activation of glycogenolysis by $\mathrm{Ca}^{2+}$-dependent hormones.
\end{abstract}

Accumulated evidence indicates that the activation of glycogenolysis by $\alpha$-adrenergic agonists, vasopressin and angiotensin II is mediated through a cyclic AMP-independent but $\mathrm{Ca}^{2+}$-dependent process (Kirk and Hems, 1974; Blackmore et al., 1978). The actions of these hormones are accompanied by marked changes in cellular $\mathrm{Ca}^{2+}$ fluxes which seem to elevate the cytosolic $\mathrm{Ca}^{2+}$ concentration (Blackmore et al., 1978; Chen et al., 1978 Blackmore et al., 1979; Murphy et al., 1980). Phosphorylase kinase, a key enzyme in glycogen metabolism, is known to be $\mathrm{Ca}^{2+}$-dependent (Khoo and Steinberg, 1975; Assimacopoulos-Jeannet et al., 1977). Recently, it has

\section{Received April 13, 1982}

Abbreviations: Cyclic GMP, guanosine $3^{\prime}: 5^{\prime}$-cyclic monophosphate; dibutyryl cyclic AMP, $\mathrm{N}^{6}, \mathrm{O}^{2}$-dibutyryl adenosine $3^{\prime}: 5^{\prime}$-cyclic monophosphate. become evident that $\mathrm{Ca}^{2+}$ dependence of many physiological processes is related to calmodulin (Cheung, 1980). It has also been shown that calmodulin activates phosphorylase kinase of skeletal muscle (Walsh et al., 1980). These results indicate the possibility that calmodulin may be involved in the regulation of hepatic glycogenolysis by those $\mathrm{Ca}^{2+}$-dependent hormones.

Phenothiazine derivatives such as chlorpromazine and trifluoperazine have been used as a tool to study the role of calmodulin because these drugs were shown to inhibit the expression of biological activity of calmodulin (Levine and Weiss, 1977; Weiss and Levine, 1978). It is reported that these drugs significantly inhibited the activation of glycogenolysis by $\alpha$-agonist in perfused liver (Reinhart et $a l ., 1980)$ and in isolated hepatocytes (Black- 
more et al., 1981). However, in isolated hepatocytes, chlorpromazine inhibited the binding of $\alpha$-agonist to plasma membrane receptor and was without any effect on the action of either vasopressin or A23187 (Blackmore et al., 1981). From these data, they concluded that phenothiazine drugs act as an $\alpha$ adrenergic antagonist, and postulated that the effect of these drugs cannot be ascribed to their interaction with calmodulin. However, as has been indicated in our previous work (Kimura et al., 1981), the responses of perfused liver to some pharmacological agents are not necessarily the same as those of isolated hepatocytes. From a physiological point of view, the perfused liver system seems more reliable because it maintains normal morphological and functional integrity. Therefore, before concluding that phenothiazine derivatives are $\alpha$-adrenergic antagonists, the mode of action of these drugs should be carefully investigated.

The present study was performed to investigate the effect of trifluoperazine, a more potent inhibitor of calmodulin action than chlorpromazine, on the regulation of hepatic glycogenolysis employing a liver perfusion system. Contrary to the results in isolated hepatocytes, trifluoperazine inhibited the activation of glycogenolysis not only by phenylephrine but also by vasopressin and angiotensin II. The effect of trifluoperazine on vasopressin and angiotensin II was not related to its $\alpha$-antagonistic activity. Therefore, the possibility that trifluoperazine inhibits the actions of $\mathrm{Ca}^{2+}$-dependent hormones in vivo through the interaction with calmodulin still remains open.

\section{Materials and Methods}

Chemicals: Phenylephrine, arginine vasopressin (grade IV), angiotension II, bovine serum albumin (Fr. V), cyclic AMP, dibutyryl cyclic AMP and phentolamine were obtained from Shigma Chemical Co. (St. Louis, Mo.). Glucagon was purchased from NOVO Industry (Copenhagen, Denmark). ${ }^{45} \mathrm{CaCl}_{2}(18.6 \mathrm{mCi} /$ $\left.\mathrm{mg} \mathrm{Ca}{ }^{2+}\right)$ and D-[U-14 C]-glucose-1-phosphate $(240 \mathrm{mCi} /$ mmol) were obtained from New England Nuclear (Boston, Mass.). Trifluoperazine was kindly donated by Yoshitomi Seiyaku Co. (Osaka, Japan). All other chemicals were of reagent grade and obtained from local suppliers.

Animals: Male Wister rats weighing about $200 \mathrm{~g}$ were obtained from Shizuoka Experimental Animal Co. (Shizuoka, Japan) and were raised on regular rat chow (Funabashi Farm, Chiba) and tap water ad libitum. All experiments were performed with fed rats.

Liver Perfusion: All perfusion experiments were carried out between 10 and $11 \mathrm{am}$. Under pentobarbital anesthesia $(50 \mathrm{mg} / \mathrm{kg}$, ip), livers were perfused in situ in a flow-through system as described elsewhere (Kimura et al., 1981). Hormones or cyclic nucleotides were added at $30 \mathrm{~min}$ after the beginning of the perfusion. Trifluoperazine was added $10 \mathrm{~min}$ before the addition of the hormones. Small pieces of liver tissue $(30-40 \mathrm{mg})$ were resected at the indicated times, frozen immediately with dry-ice and stored at $-70^{\circ} \mathrm{C}$ until phosphorylase $a$ assay, cyclic AMP, or cyclic GMP determinations. Leakage of the perfusate by these resections was negligible.

${ }^{45} \mathrm{Ca}^{2+}$ efflux study: In experiments for studying ${ }^{45} \mathrm{Ca}^{2+}$ efflux, livers were perfused with $200 \mathrm{ml}$ of KrebsRinger-Tris (20 mM, pH 7.4) buffer containing $0.01 \%$ bovine serum albumin and $1 \mathrm{mM} \mathrm{CaCl} 2$ with $50 \mu \mathrm{Ci}$ of ${ }^{45} \mathrm{Ca}^{2+}$ for $45 \mathrm{~min}$ in a recirculating system. Then the livers were perfused in a flow-through system with the buffer containing $1 \mathrm{mM} \mathrm{CaCl}_{2}$ in which trifluoperazine was also added when indicated. Hormones were added 15 min after changing to a flow-through system. The radioactivity of the effluent was determined with a scintillation spectrometer (Beckman, Model LS-3150P).

\section{Phosphorylase a assay}

Phosphorylase $a$ activity in the liver was determined using a method of Gilboe et al. (1972). Frozen liver tissue $(10-20 \mathrm{mg}$ ) was homogenized with $5 \mathrm{ml}$ of $50 \mathrm{mM}$ $\mathrm{KF}$ buffer containing $10 \mathrm{~mm}$ EDTA, pH 7.0 at $4^{\circ} \mathrm{C}$. The homogenate was centrifuged for $10 \mathrm{~min}$ at $12,000 \times$ $g$ and the supernatant was diluted to $1: 4$ with $50 \mathrm{~mm}$ 2-(N-morpholino)-ethanesulfonic buffer, $\mathrm{pH}$ 6.1, containing $50 \mathrm{~mm}$ FK and $60 \mathrm{~mm} 2$-mercaptoethanol. The assay was started with the addition of $30 \mu \mathrm{l}$ of the enzyme extract to $60 \mu \mathrm{l}$ of an assay mixture containing $200 \mathrm{~mm} \mathrm{KF}, 1 \%$ rabbit liver glycogen and $100 \mathrm{~mm}$ D- $\left[\mathrm{U}-{ }^{14} \mathrm{C}\right]$-glucose-1-phosphate, $\mathrm{pH}$ 6.1. The reaction was conducted for $20 \mathrm{~min}$ at $30^{\circ} \mathrm{C}$ and terminated by pipetting $75 \mu \mathrm{l}$ aliquot onto Whatman 31-ET filter paper, and the radioactivity of the filter paper was determined. Data were expressed as specific activity in term of $\mu \mathrm{mol}$ glucose-1-phosphate incorporated into glycogen per min per g protein, or the per cent value to the basal activity for each experiment. 
Determination of glucose, cyclic AMP, cyclic GMP and protein: The glucose concentration in the effluent fluid was determined by the glucose oxidase-peroxidase method (Boehlinger-Mannheim Co.). Cyclic AMP and cyclic GMP in liver tissue were extracted with $6 \%$ trichloroacetic acid, and their concentrations were determined by radioimmunoassay of Steiner et al, (1972) after succinylation. Protein was determined by the method of Lowry (1951) using bovine serum albumin as a standard. All data were expressed as mean \pm S.E., and Student's $t$ test was employed for statistical analyses.

\section{Results}

Effect of trifluoperazine on the activation of glucose output

Figure 1 shows the effect of $100 \mu \mathrm{M}$ trifluoperazine on the time course of the activation of glucose output. Continuous perfusion of all hormones, cyclic AMP, and its dibutyryl derivative elicited a rapid and prolonged increase in glucose output which became significant by 1 min and reached a peak between 4 and $5 \mathrm{~min}$. Glycogenolytic effects of $5 \mu \mathrm{M}$ phenylephrine (Fig. 1A), $20 \mathrm{~nm}$ vasopressin (Fig. 1B) and $10 \mathrm{~nm}$ angiotensin II (Fig. 1C) were significantly inhibited from as early as 1-2 min by the simultaneous perfusion of $100 \mu \mathrm{M}$ trifluoperazine. However, those of $1.4 \mathrm{nM}$ glucagon (Fig. 1D), $100 \mu \mathrm{M}$ cyclic AMP (Fig. 1E), or $10 \mu \mathrm{M}$ dibutyryl cyclic AMP (Fig. 1F) were not affected by trifluoperazine.

Figure 2 shows the effects of trifluoperazine on the dose-response relationship of the net increase in glucose output by each agent. One hundred nм to $5 \mu \mathrm{M}$ phenylephrine stimulated glucose output in a dose-dependent manner. Trifluoperazine reduced the maximal response to phenylephrine by $60 \%$ (Fig. 2A). The effect of vasopressin was dose-dependent between $0.05-1 \mathrm{~nm}$, and trifluoperazine shifted the curve about one order of magnitude to the right (Fig. 2B). The effect of angiotensin II was also dose-dependent between $0.1-5 \mathrm{nM}$, and trifluoperazine reduced the maximal response by $60 \%$ (Fig. 2C). Glucagon at the concentration of 6-100 pM elicited a dose-

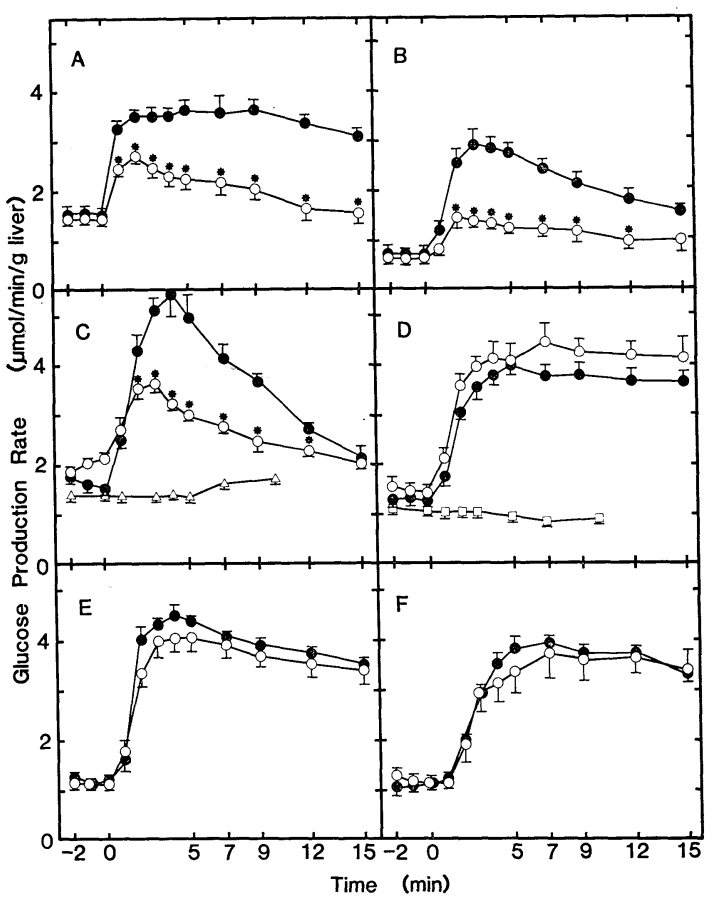

Fig. 1. Effect of trifluoperazine on the time course of the activation of glucose output.

Thirty minutes after beginning of perfusion $(0 \mathrm{~min}$ in the figure), either $5 \mu \mathrm{M}$ phenyleprine (A), $20 \mathrm{nM}$ vasopressin (B), $10 \mathrm{nM}$ angiotension II (C), $1.4 \mathrm{~nm}$ glucagon (D), $100 \mu \mathrm{M}$ cAMP (E), or $10 \mu \mathrm{M}$ dibutyryl cyclic AMP (F) was added to the perfusate. Trifluoperazine $(100 \mu \mathrm{M})$ was perfused from $10 \mathrm{~min}$ before the addition of these agents when indicated. - - each agent only: $\bigcirc-\bigcirc$, agent plus trifluoperazine: $\square-\square$, perfusate only: and $\Delta-\Delta$, trifluoperazine only. Each point and vertical bar represent the mean and S.E. from 4 to 14 independent experiments. Values which are significantly different from those obtained without trifluoperazine are indicated in the figure with an asterisk; * at least $\mathrm{P}<0.05$.

dependent increase in glucose output which was not inhibited by trifluoperazine (Fig. 2D).

The inhibitory effect of trifluoperazine on the phenylephrine-induced glucose output was dose-dependent between $0.5-10 \mu \mathrm{M}$, with the half maximal inhibitory concentration, $3 \mu \mathrm{M}$ (Fig. 3). Approximately the same range of concentration of trifluoperazine was also effective on vasopressin and angiotensin II. 


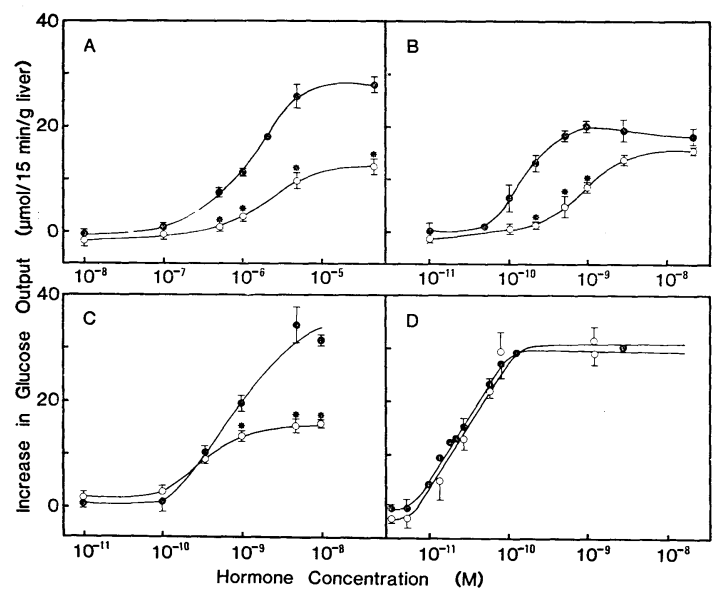

Fig. 2. Effect of trifluoperazine on the dose-response relationship of the net increase in glucose output.

Livers were perfused with different concentrations of phenylephrine (A), vasopressin (B), angiotension II (C) or glucagon (D) with or without $100 \mu \mathrm{M}$ trifluoperazine, as in Fig. 1. Net increase in glucose output was calculated by using mean glucose production rate during $3 \mathrm{~min}$ before hormone administration as the basal glucose production rate. each hormone only: $\bigcirc-\bigcirc$, hormone plus trifluoperazine.

Effect of phentolamine on the activation of glucose output

Blackmore et al. (1981) and Tilley et al. (1981) reported that trifluoperazine acted as the $\alpha$-adrenergic antagonist in isolated hepatocytes. To study whether the inhibitory effect of trifluoperazine on the actions of vasopressin and angiotensin II observed in our system was

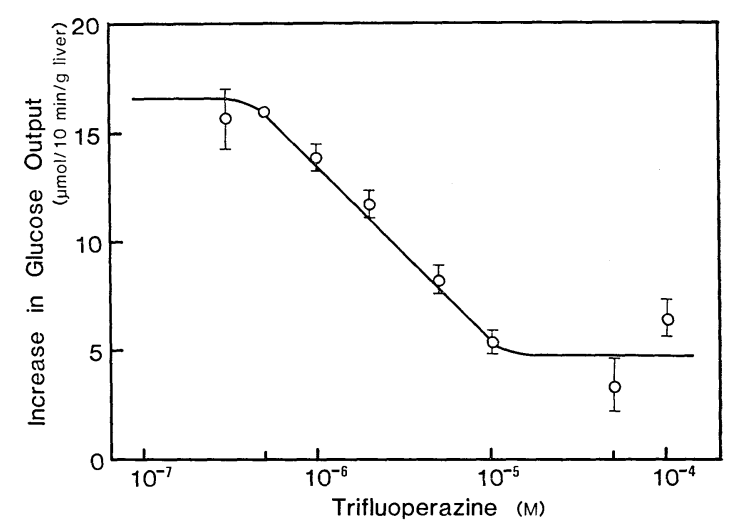

Fig. 3. Dose-response curve of the inhibitory effect of trifluoperazine on the net increase in glucose output by phenylephrine.

Livers were perfused for 10 min with $5 \mu \mathrm{M}$ phenylephrine and various concentration of trifluoperazine. The number of experiments for each point was at least 2 to 12 .

related to this property of the drug, the effects of phentolamine on the action of vasopressin and angiotensin II were examined (Table 1). A high concentration of phentolamine $(40 \mu \mathrm{M})$ inhibited the activation of glucose output by phenylephrine but not those by vasopressin or angiotensin II.

Effect of trijtuoperazine on the activation of phosphorylase by glucagon and phenylephrine

Basal phosphorylase $a$ activity determined on the liver before the administration of hormones was not affected by $100 \mu \mathrm{M}$ tri-

Table 1. Effect of phentolamine on the activation of glucose output by phenylephrine, vasopressin and angiotensin II.

\begin{tabular}{|c|c|c|c|c|}
\hline \multirow{3}{*}{ Hormones } & \multicolumn{3}{|c|}{$\begin{array}{c}\text { Glucose Output } \\
(\mu \mathrm{mol} / 15 \mathrm{~min} / \mathrm{g} \text { liver })\end{array}$} & \multirow{3}{*}{$\begin{array}{c}\text { Livel of } \\
\text { Significance }\end{array}$} \\
\hline & & \multicolumn{2}{|c|}{ Phentolamine } & \\
\hline & & $0 \mu \mathrm{M}$ & $40 \mu \mathrm{M}$ & \\
\hline Phenylephrine & $5 \mu \mathrm{M}$ & $25.10 \pm 1.58(8)$ & $2.10 \pm 0.32$ & $\mathrm{P}<0.001$ \\
\hline Vasopressin & $20 \mathrm{nM}$ & $22.07 \pm 1.29(6)$ & $25.23 \pm 0.67(3)$ & $P>0.05$ \\
\hline Angiotensin II & $10 \mathrm{nM}$ & $31.16 \pm 2.52(7)$ & $26.22 \pm 0.63(3)$ & $\mathrm{P}>0.05$ \\
\hline
\end{tabular}

Livers were perfused with either phenylephrine, vasopressin or angiotensin II as described in Methods. When indicated, $40 \mu \mathrm{M}$ phentolamine was added from $10 \mathrm{~min}$ before the perfusion of these hormones. 


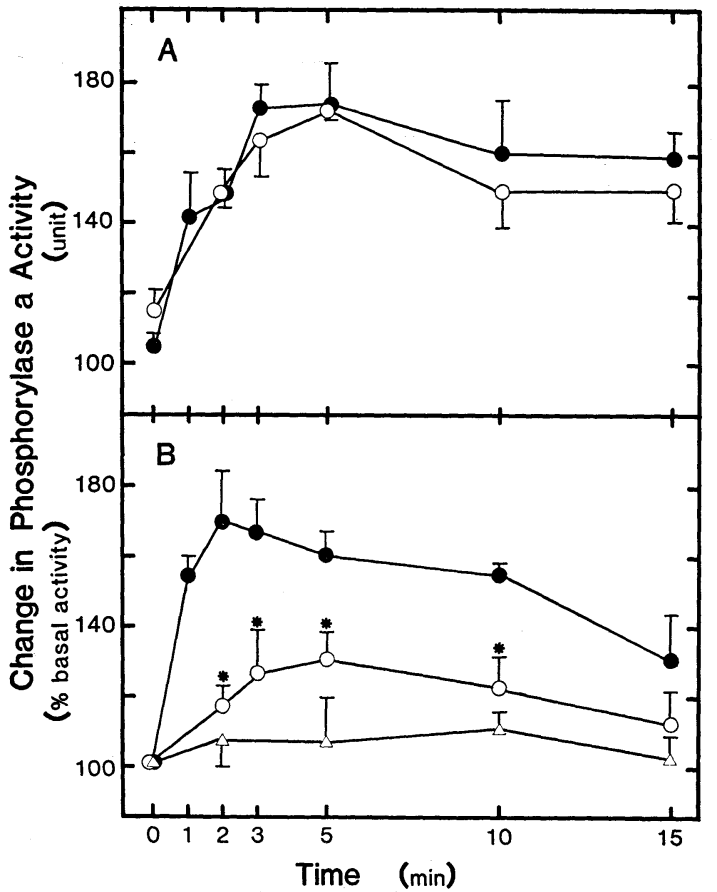

Fig. 4. Effect of trifluoperazine on the activation of phosphorylase by glucagon and pehylephrine.

Pieces of liver tissues were resected during perfusion of $1.4 \mathrm{nM}$ glucagon (A) or $5 \mu \mathrm{M}$ phenylephrine (B) with or wothout $100 \mu \mathrm{M}$ trifluoperazine. Liver tissues were processed, and phsophorylase a activity was determined as in Materials and Methods. The activity was expressed as specific activity in terms of $\mu \mathrm{mol}$ glucose-1-phosphate incorporated into glycogen per minute per $\mathrm{g}$ protein in Fig. 4A, and per cent change in basal activity in Fig. 4B. Values significantly different from those obtained without trifluooprazine were indicated with an asterisk; * at least $\mathrm{P}<0.05$. The number of experiment is 4 to 8 . each hormone only: $\bigcirc-\bigcirc$, hormone plus trifluoperazine.

fluoperazine (control, 103.0 $\pm 5.4 \mathrm{U} \quad(\mathrm{n}=24)$; with trifluoperazine, $115.2 \pm 5.2 \mathrm{U} \quad(\mathrm{n}=19))$. Trifluoperazine was also without any effect on the activation of phosphorylase by glucagon (Fig. 4A). The time course of phosphorylase activation by phenylephrine is shown in Fig. 4B. Trifluoperazine significantly inhibited the phenylephrine-induced activation of phosphorylase at all time points examined.

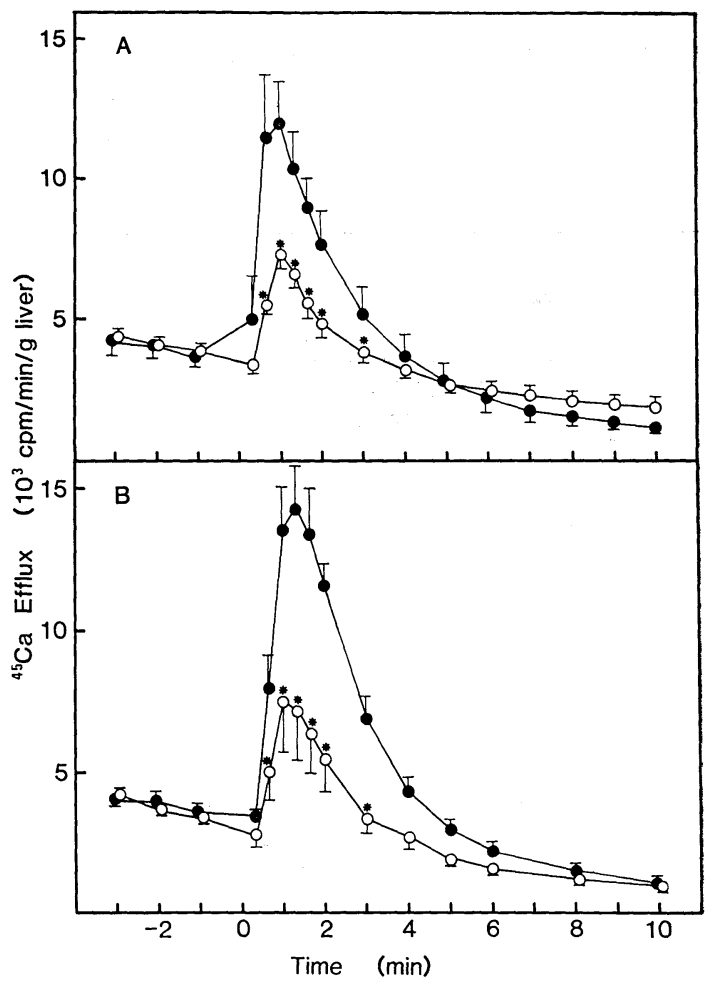

Fig. 5. Effect of trifluoperazine on phenylephrineand vasopressin-induced ${ }^{45} \mathrm{Ca}$ efflux from ${ }^{45} \mathrm{Ca}$ preloaded liver.

Livers were pre-perfused for $45 \mathrm{~min}$ in a recirculating system with $1 \mathrm{mM}{ }^{45} \mathrm{CaCl}_{2}$. Following $15 \mathrm{~min}$ wash-out perfusion with Krebs-Ringer-Tris buffer in a flow-through system, livers were perfused with $5 \mu \mathrm{M}$ phenylephrine (A) or $20 \mathrm{nM}$ vasopressin (B). Trifluoperazine $(100 \mu \mathrm{M})$ was added from $10 \mathrm{~min}$ before the addition of each hormone. The number of experiment is 3 to 5 . - , hormone only: $\bigcirc-\bigcirc$, hormone plus trifluoperazine.

Effect of trifluoperazine on ${ }^{45} \mathrm{Ca}^{2+}$ efflux

Phenylephrine (Fig. 5A) or vasopressin (Fig. 5B) caused a rapid and transient increase in ${ }^{45} \mathrm{Ca}^{2+}$ efflux from ${ }^{45} \mathrm{Ca}^{2+}$ pre-loaded liver. Trifluoperazine significantly inhibited those effects of phenylephrine and vasopressin without changing the time course of ${ }^{45} \mathrm{Ca}^{2+}$ efflux. As shown in Table 2, the total amount of ${ }^{45} \mathrm{Ca}^{2+}$ released following the administration of either phenylephrine, vasopressin or angioten- 
Table 2. Effect of trifluoperazine on ${ }^{45} \mathrm{Ca}$ efflux

\begin{tabular}{|c|c|c|c|c|}
\hline \multirow{3}{*}{ Hormones } & \multicolumn{3}{|c|}{$\begin{array}{c}\text { Released }{ }^{45} \mathrm{Ca} \\
(\mathrm{cpm} / 10 \mathrm{~min} / \mathrm{g} \text { liver })\end{array}$} & \multirow{3}{*}{$\begin{array}{l}\text { Level of } \\
\text { Significance }\end{array}$} \\
\hline & & \multicolumn{2}{|c|}{ Trifluoperazine } & \\
\hline & & $0 \mu \mathrm{M}$ & $100 \mu \mathrm{M}$ & \\
\hline Phenylephrine & $5 \mu \mathrm{M}$ & $16,528 \pm 3.492(4)$ & $4.979 \pm 1.282(5)$ & $\mathrm{P}<0.02$ \\
\hline Vasopressin & $20 \mathrm{nM}$ & $25,192 \pm 3,730(5)$ & $9,154 \pm 1,499(4)$ & $\mathrm{P}<0.05$ \\
\hline Angiotensin II & $10 \mathrm{nM}$ & $27,332 \pm 1,418(3)$ & $20,221 \pm 1,200$ & $\mathrm{P}<0.02$ \\
\hline
\end{tabular}

Liver was pre-perfused in a recirculating system with $\mathrm{KRT}$ buffer containing $1 \mathrm{mM}{ }^{45} \mathrm{CaCl}_{2}$ for $45 \mathrm{~min}$. Then the liver was perfused in a flow-through system, and trifuoperazine was added to the buffer when indicated. Fifteen min after the switch to a flow-through system, phenylephrine, vasopressin or angiotensin II was added to the buffer. Radioactivity in each fraction was counted in a scintillation spectrometer.

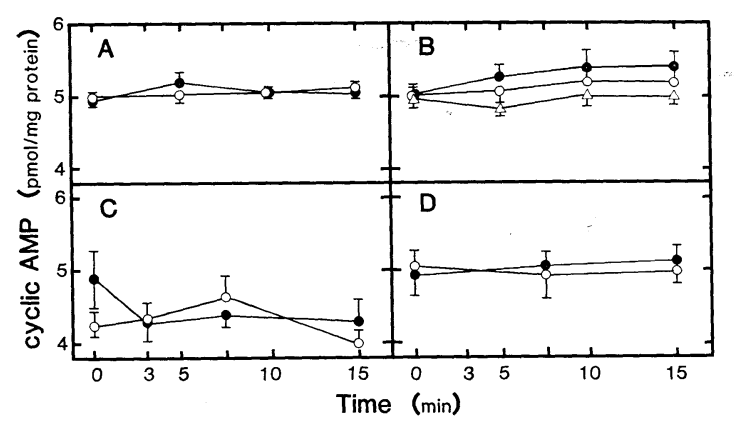

Fig. 6. Effect of trifluoperazine on cyclic AMP concentration in perfused rat liver.

Livers were perfused with either $5 \mu \mathrm{M}$ phenylephrine (A and B), $20 \mathrm{nM}$ vasopressin (C), or $10 \mathrm{nM}$ angiotensin II (D) in the presence (A, C, D) or in the absence (B) of $1 \mathrm{mM} \mathrm{CaCl}_{2}$ as in Fig. 1. Pieces of liver tissue were resected at the indicated time and processed as in METHOD. Values which are significantly different from those without trifluoperazine are indicated with asterisk: * at least $\mathrm{P}<$ 0.05 . The number of experiments is 4 to 11 .

hormone only: $\bigcirc-\bigcirc$, hormone plus trifluoperazine.

sin II was decreased significantly by trifluoperazine.

Effect of trifluoperazine on cyclic nucleotides level

The effects of trifluoperazine on the tissue cyclic nucleotide level were studied to see whether the inhibitory effect of trifluoperazine is related to the change in tissue cyclic AMP or cyclic GMP levels. However, in the presence of $1 \mathrm{mM} \mathrm{Ca}^{2+}$, no significant changes in the cyclic AMP kevel were detected following the perfusion of $5 \mu \mathrm{M}$ phenylephrine (Fig. 6A), 20 $\mathrm{nM}$ vasopressin (Fig. 6C), or $10 \mathrm{~nm}$ angiotensin II (Fig. 6D) either with or without $100 \mu \mathrm{M}$ trifluoperazine. Identical results were obtained for phenylephrine (Fig. 6B) when $\mathrm{Ca}^{2+}$-free perfusate was used. No significant changes in the cyclic GMP level were detected following the administration of each hormone either with or without trifluoperazine (data not shown).

\section{Discussion}

The present study clearly demonstrates that trifluoperazine specificially inhibits the activation of glycogenolysis by hormones which are believed to be dependent on $\mathrm{Ca}^{2+}$ ion for their actions, i.e. phenylephrine, vasopressin and angiotensin II. These results are different from those in isolated hepatocytes (Blackmore et al., 1981). First, trifluoperazine significantly inhibited the effect of vasopressin. It is possible that the concentration of vasopressin they used $(555 \mathrm{~nm})$ was so high that chlorpromazine $\left(10^{-6} \mathrm{M}\right)$ could not inhibit the effect of vasopressin. In fact, the concentration of vasopressin they used is extremely high from the physiological range. As shown in Fig. 2, the inhibitory effect of trifluoperazine was demonstrable only when the concentrations of vasopressin were relatively low (less than $1 \mathrm{nM})$. Alternatively, some properties of 
plasma membranes may have been changed during the isolation procedures, as indicated by our previous report (Kimura et al., 1981), resulting in the failure of chlorpromazine to inhibit vasopressin action. Second, the drug inhibited also the effect of angiotensin II. Although the effect of phenothiazine drugs on the glycogenolytic action of angiotensin II has never been studied, Tilley et al. (1981) reported that chlorpromazine did not affect the activation of gluconeogenesis by angiotensin II. However, it should be noted that $\mathrm{Ca}^{2+}$ dependent hormones are weak activators of gluconeogenesis, and the role of $\mathrm{Ca}^{2+}$ in gluconeogenesis is quite obscure (Glinsmann et al., 1969). Removal of $\mathrm{Ca}^{2+}$ does not prevent the activation of gluconeogenesis by those $\mathrm{Ca}^{2+}$ dependent hormones, and $\mathrm{Ca}^{2+}$ ionophore A23287 actually inhibits gluconeogenesis (Friedmann et al., 1979). On the other hand, the role of $\mathrm{Ca}^{2+}$ in the glycogenolytic effect of angiotensin II seems more settled. Therefore, if the action of trifluoperazine is related to the action of $\mathrm{Ca}^{2+}$ (e.g. interaction with calmodulin, $\mathrm{Ca}^{2+}$ flux), the angiotensin II-induced activation of glycogenolysis may be inhibited by the drug as observed in our system. Third, although phenothiazine drugs are reported to inhibit the binding of $\alpha$-agonist to receptors in a competitive manner in isolated hepatocytes (Blackmore et al., 1981; Tilley et al., 1981), it is not the case in the perfused liver system, as shown in Fig. 2. Furthermore, typical $\alpha$ antagonist phentolamine showed no effect on the activation of glycogenolysis by vasopressin and angiotensin II. The failure of the $\alpha$ antagonist to inhibit the action of vasopressin and angiotensin II was also reported by Garrison et al. (1979). Therefore, the inhibitory effect of trifluoperazine at least on the action of vasopressin and angiotensin II should be exerted through its property other than $\alpha$ antagonist. Thus, the results on the effect of phenothiazine drugs on the glycogenolysis in perfused liver largely differ from those in isolated hepatocytes. Therefore, the conclusion drawn from the observation in isolated hepatocytes cannot necessarily be applied to physiological conditions.

In the present system the modes of trifluoperazine action on phenylephrine or angiotensin II and on vasopressin are different, suggesting different sites of trifluoperazine action among these hormones. Since the effects of the drug on phosphorylase activation by glucagon and by phenylephrine are different, these sites appear to be located before the activation of phosphorylase. In addition, the present effect of the drug was not associated with a change in tissue cyclic AMP or cyclic GMP level and the drug elicited no effect on the activation of glycogenolysis by glucagon or cyclic AMP. Therefore, cyclic nucleotides-related process may not be involved. On the other hand, the effect of trifluoperazine was specific for all $\mathrm{Ca}^{2+}$-dependent hormones, and was associated with the inhibition of $\mathrm{Ca}^{2+}$ efflux induced by these hormones. Therefore, it is conceivable that the mechanism of trifluoperazine action is somehow related to the change in the $\mathrm{Ca}^{2+}$ flux or $\mathrm{Ca}^{2+}$-dependent process induced by these hormones, although it is still possible that the drug inhibits the binding of all these $\mathrm{Ca}^{2+}$-dependent hormones to their receptors. It is becoming evident that calmodulin modulates the movement of $\mathrm{Ca}^{2+}$ within the cell or across plasma membranes. For example, calmodulin activates $\left(\mathrm{Ca}^{2+}-\mathrm{Mg}^{2+}\right)$ dependent ATPase of erythrocytes (Jarret and Penninston, 1970; Gopinath and Vincenzi, 1977) and fat cells (Pershadsingh et al., 1980). Trifluoperazine significantly inhibits the activation of $\mathrm{Ca}^{2+}$ efflux as well as thyrotropin secretion from pituitary by TRH or depolarization (Fleckman et al., 1981). These observations support the concept that the blockade of calmodulin action may result in an inhibition of hormone-induced $\mathrm{Ca}^{2+}$ mobilization from the cells, as was observed in the present study. Moreover, it is shown that 1) Skeletal muscle contains $\mathrm{Ca}^{2+}$ - and calmodulin-dependent protein kinase which activates phosphorylase kinase (Waisman et al., 1978); 2) Phosphorylase kinase of skeletal muscle contains calmodu- 
lin as its subunit (Cohen et al., 1978); 3) Hepatic phosphorylase kinase is also $\mathrm{Ca}^{2+}$ stimulatable (Khoo and Steinberg, 1975; Assimacopoulos-Jeannet et al., 1977). In view of the possible involvement of calmodulin in these processes and the specific effect of trifluoperazine on all $\mathrm{Ca}^{2+}$-dependent hormones, the possibility that phenothiazine drugs interact with calmodulin in vivo in liver still remains open. Therefore, it seems too early to conclude that these drugs act solely as an $\alpha$-antagonist. The mechanism of action of phenothiazine drugs should be further examined.

\section{Acknowledgments}

This work was supported in part by a Grant-in-Aid for Scientific Research from the Ministry of Education, Japan.

\section{References}

Assimacopoulos-Jeannet, F.D., P. F. Blackmore and J. H. Exton (1977). Studies on $\alpha$-adrenergic activation of hepatic glucose output. Studies on role of calcium in $\alpha$-adrenergic activation of phosphorylase. J. Biol. Chem. 252, 2662-2669.

Blackmore, P., F., L. L. Brumley, J. L. Marks and J. H. Exton (1978). Studies on $\alpha$-adrenergic activation of hepatic glucose output. Relationship between $\alpha$-adrenergic stimulation of calcium efflux and activation of phosphorylase in isolated rat liver parenchymal cells. J. Biol. Chem. 253, 4851-4858.

Blackmore, P. F., J.-P. Dehaye and J. H. Exton (1979). Studies on $\alpha$-adrenergic activation of hepatic glucose output. The role of mitochondrial calcium release in $\alpha$-adrenergic activation of phosphorylase in perfused rat liver. J. Biol. Chem. 254, 6945-6950.

Blackmore, P. F., M. F. EL-Refai, J.-P. Dehaye, W. G. Strickland, B. P. Hughes and J. H. Exton (1981). Blockade of hepatic $\alpha$-adrenergic receptors and responses by chlorpromazine and trifluoperazine. FEBS Lett. 123, 245-248.

Chen, J.-L. J., D. F. Babcock and H. A. Lardy (1978). Norepinephrine, vasopressin, glucagon, and A23187 induced efflux of calcium from an exchangeable pool in isolated hepatocytes. Proc. Natl. Acad. Sci. U.S.A. 75, 2234-2238.

Cheung, W. Y. (1980). Calmodulin plays a pivotal role in cellular regulation. Science 207, 19-27.

Cohen, P., A. Burchell, J. G. Foulkes and P. T. Cohen
(1978). Identification of the $\mathrm{Ca}^{2+-}$-dependent modulater protein as the fourth subunit of rabbit skeletal muscle phosphorylase kinase. FEBS Lett. 92, 287293.

Fleckman, A., J. Erlichman, U. K. Schubart and N. Fleisher (1981). Effect of trifluoperazine, D 600, and phenyntoin on depolarization- and thyrotropinreleasing hormone-induced thyrotropin release from rat pituitary tissue. Endocrinology 108, 2072-2077.

Friedmann, N., P. Divakaran, J. Kirkland, S. Kimura and J. Wood (1979). Effects of the calcium ionophore A23187 on liver metabolism. J. Pharmacol. Exp. Ther. 211, 127-132.

Garrison, J. C., M. K. Borland, V. A. Florio and D. A. Twible (1979). The role of calcium as a mediator of the effects of angiotensin II, catecholamines, and vasopressin on the phosphorylation and activity of enzymes in isolated hepatocytes. J. Biol. Chem. 254, 7147-7156.

Gilboe, D. P., K. L. Larson and F. Q. Nuttall (1972). Radioactive method for the assay of glycogen phosphorylases. An. Biochem. 47, 20-27.

Glinsmann, W. H., E. P. Hern, L. G. Linarelli and R. V. Farese (1969). Similarities between effects of adenosine $3^{\prime}, 5^{\prime}$-monophosphate and guanosine $3^{\prime}, 5^{\prime}$ monophosphate on liver and adrenal metabolism. Endocrinology 85, 711-719.

Gopinath, R. M. and F. F. Vincenzi (1977). Phosphodiesterase protein activator mimics red blood cell cytoplasmic activator of $\left(\mathrm{Ca}^{2+}-\mathrm{Mg}^{2+}\right)$ ATPase. Biochem. Biophys. Res. Commun. 77, 1203-1209.

Jarett, H. W. and J. T. Penniston (1970). Partial purification of the $\mathrm{Ca}^{2+}-\mathrm{Mg}^{2+}$ ATPase activator from human erythrocytes: Its similarity to the activator of $3^{\prime}: 5^{\prime}$-cyclic nucleotide phosphodiesterase. Biochem. Biophys. Res. Commun. 77, 1210-1216.

Khoo, J. C. and D. Steinberg (1975). Stimulation of rat liver phosphorylase kinase by micromolar concentration of $\mathrm{Ca}^{2+}$. FEBS Lett. 57, 68-72.

Kimura, S., Y. Koide, R. Tada, K. Abe and E. Ogata (1981). Inhibitory effect of calcium channel blockers on $\alpha$-adrenergic activation of glycogenolysis and calcium efflux in perfused rat liver. Endocrinol. Japon 28, 69-78.

Kirk, C. J. and D. A. Hems (1974). Hepatic action of vasopressin: lack of a role of adenosine- $3^{\prime}, 5^{\prime}$ cyclic monophosphate. FEBS Lett. 128-131.

Levine, R. M. and B. Weiss (1977). Mechanism by which psychotropic drugs inhibit adenosine cyclic 3',5'-monophosphate phosphodiesterase of brain. Mol. Pharmaco'. 13, 690-697.

Lowry, O. H., N. J. Rosebrogh, A. L. Farr and R. J. Randall (1951). Protein measurement with the folin phenol reagent. J. Biol. Chem. 193, 265-275.

Murphy, E., K. Coll, T. L. Rich and J. R. Williamson (1980). Hormonal effects on calcium homeostasis in isolated hepatocytes. J. Biol. Chem. 255, 6600 6608.

Pershadsingh, H. A., M. Landt and J. M. McDonald 
(1980). A high affinity calcium-stimulated magnesium-dependent adenosine triphosphatase in rat plasma membranes. J. Biol. Chem. 255, 8983-8986.

Reinhart, P. H., M. W. Taylor and F. L. Bygrave (1980). Trifluoperazine, an inhibitor of calmodulin action, antagonises phenylephrine-induced metabolic responses and mitochondrial calcium fluxes in liver. FEBS Lett. 120, 71-74.

Steiner, A. L., A. S. Pagliara, L. R. Chase and D. M. Kipnis (1972). Radioimmunoassay for cyclic nucleotides. II. Adenosine $3^{\prime}, 5^{\prime}$-monophosphate and guanosine $3^{\prime}, 5^{\prime}$-monophosphate in mammalian tissues and body fluids. J. Biol. Chem. 247, 1114-1120.

Tilley, L., R. J. Summers, T. G. Redgrave and B. E. Kemp (1981). Inhibition of phenylephrine-stimulated gluconeogenesis by chlorpromazine is mediated by $\alpha$-adrenergic receptors. FEBS Lett. 126, 313-317.

Waisman, D. M., T. J. Singh and J. H. Wang (1978). The modulator-dependent protein kinase. A multifunctional protein kinase activatable by the $\mathrm{Ca}^{2+}$ dependent modulator protein of the cyclic nucleotide sytem. J. Biol. Chem. 253, 3387-3390.

Walsh, K. X., M. D. Millikin, K. K. Schlender and E. M. Reiman (1980). Stimulation of phosphorylase b kinase by the calcium-dependent regulator. $J$. Biol. Chem. 255, 5036-5042.

Weiss, B. and R. M. Levine (1978). Mechanism for selectively inhibiting the activation of cyclic nucleotide phosphodiesterase and adenylate cyclase by antipsychotic agents. In: Advances in Cyclic Nucleotide Research (W. J. George and L. J. Ignarro eds.) Raven Press, New York, vol. 9, pp. 285-303. 